\title{
Luigi Sturzo and Civil Economy
}

\author{
Stefano Zamagni*
}

University of Bologna, Johns Hopkins University SAIS Europe, Bologna, Italy and Pontifical Academy of Social Sciences

\section{Received January 24 2018; Accepted February 242018}

Abstract: The paper defends the thesis that a proper understanding of Sturzo's thought and work can be achieved only within the perspective of the civil economy paradigm. After exposing the main pillars characterizing the civil economy research program, the argument proceeds indicating the reasons why Sturzo did not consider adequate, for a country like Italy, the proposal of the social market economy. The paper concludes suggesting same reasons to explain the fin de non recevoir of the political establishment with respect to Sturzo's testimony.

Keywords: Luigi Sturzo • Civil economy • Social market economy • Statism • Positive liberty

\section{Introduction}

Luigi Sturzo's lot, like that of many great thinkers and famous figures who were far ahead of their time, was one among incomprehension, rejection, and at times even scorn. The contemporaries of this famous thinker from Caltagirone in eastern Sicily were incapable of grasping the truly innovative character of his economic and social thought; and their inexcusable shortsightedness prevented them from ever appreciating the true value of his political vision. Their sterile game of pigeonholing people means that they failed to grasp the true essence of the man and his ideas.

Thus, in the eyes of early 20th-century traditional Catholics, Luigi Sturzo was a disconcerting radical to be kept at a safe distance, while the Catholics on the other side of the political divide, that is, the followers of Romolo Murri, viewed the priest from Caltagirone as simply an enlightened conservative. On the other hand, beyond the Catholic sphere, Sturzo's thoughts were equated with insignificant reformism by the socialist movement, while the fascist regime saw him as an impending threat - so much so that Sturzo was forced to flee the country on 24 October 1924, finding exile first in Great Britain and then in the USA.

The most surprising aspect of this matter is that Luigi Sturzo continued to be ostracized even after his return to Italy on 27 August 1946, right up to his death on 9 August 1959, during what was a completely different period in the history from both cultural and political viewpoints. This "second exile," as it has been appropriately termed, was symbolized by the fact that while Italian Catholics turned for inspiration to the personalist ideas of E. Mounier and J. Maritain following the Second World War, completely Ignoring Sturzo's work. In 1959, Maritain himself, in his Homage à Don Sturzo, declared the following: "In virtue of his writings of such enormous scope, and of his practical activities. Sturzo was a leading historical figure of Italy's Christian democratic party. He realized that the Christian democrats (DCs) could not fulfill their task without solid doctrinal foundations. Hence his protracted reflections which, fed by a profoundly enlightened religious culture, have produced such a wealth of results in the field of political and social philosophy, and which in the light of the wisdom 
of Christianity have established principles justifying the ideal of justice and fraternity inherent in democracy."

Several, somewhat divergent explanations have been proffered for Luigi Sturzo's personal isolation and for the underestimation of his work. These range from jealousy of a person clearly of above-average standing to concern that the acceptance of his thoughts, and in particular of his staunch anti-statism and his opposition to the government's policy of providing aid to the South of Italy, could have led to severe criticism of the De Gasperi governments' actions and those of subsequent governments and the policy of Enrico Mattei's ENI (Italy's State Oil \& Gas Company). Statements such as "since the time of Machiavelli and Luther, the State has never ceased to pursue its own deification" were certainly not well received by those who back in the 1930s had already commenced that process of massive state intervention in the country's economy that was to continue up to the late 1980s making Italy one of the most "Soviet-like" Western countries. It should come as no surprise, therefore, that when in 1952 Sturzo was nominated senator for life, decided not to be part of the DCs, but joined a cross-party grouping in the Senate.

Without wishing to question the validity of the aforementioned, and other similar, arguments, ${ }^{2}$ I personally believe that the main reason why Sturzo has been largely forgotten in Italy is one of a cultural nature. This man was a refined intellectual with a considerable flair for philosophical and political analysis. Thus, it appears rather shortsighted to see him simply as a courageous social and political leader. The fact is that the "Sturzo question," insofar as it specifically concerns economic issues, can be approached from two different viewpoints: political economy and civil economy. As far as I know, all studies that have dealt with this question to date have adopted the political economy model as the key to interpret the writings and work of Luigi Sturzo. The results of such studies are widely known. In the view of some scholars, Sturzo was a liberal Catholic whose ideas converged with those of the social market economy (SOME) associated with the names of Ludwig von Mises (who wrote the famous work Liberalismus in 1927, in which Manchester liberalism was reinterpreted from the social viewpoint with the aim of tempering the

1 Cited in Pennisi 2009, p.197. Federico Chabod's judgement was equally as flattering: Chabod believed that the foundation of the Italian Popular Party in 1919 represented "the most important political event in 20th-century Italian history" (p.196).

2 For two recent, detailed analyses of these points, see Pagliai 2009 and Palladino 2009: both volumes contain a full bibliography regarding the question. Gabriele De Rosa's biography of Luigi Sturzo (De Rosa 1977) remains of fundamental importance, while another important work is the essay by Campanini (2001).
Austrian bourgeoisie's attraction to Nazism), Walter Eucken (founder of the review Ordo in 1940), and Wilhelm Röpke (the principal exponent of the maxims of ordoliberalism in political practice). Others have seen Sturzo as sharing the political views of Luigi Einaudi, Epicarmo Corbino, Giuseppe Pella, and others and an adversary of Alcide De Gasperi, Giorgio La Pira, Amintore Fanfani, etc., who were variously classified as interventionists, statists, or Keynesians.

If, on the other hand, we adopted the civil economy as our interpretative "beryl" (in the sense adopted by Nicolo Cusano $^{3}$ ), then we discovered not only that the divergence between Sturzo and La Pira was not so marked as has been believed up until now but also the argument that Sturzo was the precursor, or at least a great advocate, of the SOME, according to the viewpoint popularized by the Freiburg School, is groundless. Before arguing in support of my thesis, I shall briefly explain the basic features of the civil economy paradigm.

\section{What is civil economy?}

The civil economy tradition is one rooted in the 15thcentury civil humanism, a tradition that saw its golden age in the Italian enlightenment centered on Milan and, in particular, on Naples (Bruni and Zamagni, Civil Economy, Newcastle u.T. (upon Tyne), Agenda, 2016). While in Scotland, Smith and Hume were formulating their principles of political economy, during the same period research was being conducted in civil economy by Genovesi, Filangieri, and Dragonetti in Naples and by Verri, Beccaria, and Gioja in Milan. It should be pointed out that the first university chair in economics in the world was established at Naples University in 1753 and was entitled the "Chair in Civil Economy"; the first holder of that chair was Antonio Genovesi. There are several similarities between the Scottish School and the Neapolitan-Milanese School: their anti-feudal stance (with the market seen as a way out of feudal society); their consideration of luxury as a factor of social change, without being overly concerned about the "vices" of the consumers of such luxury goods; a considerable ability to grasp the cultural change that the growth of trade was producing in Europe; their acknowledgment of the essential role played by trust in the operation of a market economy; the "modernity" of their visions of society and the world. At the same time, however, there

3 "The beryl is a resplendent, colourless, and transparent stone, to which is given a concave or convex form, and those who look through it succeed in discovering things at first invisible." De Beryllo, 1458, in N. Cusano, 2017. 
was a profound difference between Scotland (political economy) and Italy (civil economy). Adam Smith, despite acknowledging the fact that human beings possess a natural tendency to be sociable (consisting in their sympathy for, and their correspondence of sentiments with, others), does not consider sociability (i.e., the relationship with others for noninstrumental reasons) to be an important factor in the operation of markets: "Civil society can exist between different people...based on the consideration of the individual utility, without any form of love or mutual affection" (Theory of Moral Sentiments, II.3.2., my italics).

Indeed, in certain passages of both the Theory of Moral Sentiments (1759) and the Wealth of Nations (1776), Smith - the thinker who formulated the most complete version of the political economy paradigm specifically stated that sentiments and benevolent behavior complicate the market mechanism, which he believed would work better if interpersonal relationships within that market were of a more strictly instrumental nature. Therefore, what is required then is a market system so perfect that there is no need for benevolence, that is, the capacity to do good, on the part of anyone concerned. In Smith's view, and in that of the tradition which was to subsequently become official economic policy, the market is the means by which to build genuinely social relationships (there can be no civil society without markets), provided that the market is free of imposed hierarchical relationships based on status; however, the market in itself is not a relational arena. The fact that market relationships are impersonal and reciprocally indifferent is not a negative thing in Smith's view, but rather a civilizing factor: this is the only way that the market can guarantee well-being and growth. Friendship and market relationships thus appear to belong to two very different, separate spheres; indeed, the existence of market relationships in the public sphere (and only in this sphere) guarantees that friendships and social relationships in the private sphere are authentic, freely chosen, and unconnected to a person's social status. If a beggar goes to the butcher's and begs, he can never be the butcher's friend outside of the market place. If, on the other hand, a former beggar walks into the butcher's shop, or into the off-license, to buy his/her products in the evening that former beggar may meet his suppliers at the pub in a more dignified manner and perhaps become their friend. In Smith's view, and in that of the official tradition of economic science, the market is civilization but not friendship, neither is it noninstrumental reciprocity or fraternity (Bruni and Sugden 2008).

Civil economy scholars radically disagree on the aforementioned aspects, which are of key importance to contemporary economic practice and theory.
In the view of Genovesi, Filangieri, and Dragonetti in Naples, of Verri, Beccaria, and Romagnosi in Milan, and in the 20th century of Luigi Sturzo and, to a certain degree, of Luigi Einaudi, as well as that of certain applied economists such as Rabbeno or Luzzatti, or the founder of business economics Gino Zappa (the Italian business economic tradition is another leading expression of the civil economic school of thought), the market, the firm, and the business sphere are also places inherently characterized by friendship, reciprocity, and actions performed gratuitously. The civil economy does not accept the idea, or rather the ideology, which is currently taken for granted, according to which the market is something radically different from the civil sphere, and as such is governed by different principles from those governing the latter. Advocates of the civil economy see the economy as essentially civil, the market as a place where people share their lives; both the economy and the market share the same basic principle, namely that of mutual aid. Genovesi's mutual aid is not the same as mutual benefit of Adam Smith: to obtain a mutual benefit a contract suffices, whereas to achieve mutual aid you need philia (close friendship) and perhaps agape (love; Pabst 2015).

The civil economy is nowadays considered to be an alternative to the Smithian understanding of the economy whereby the market is the only institution really required for democracy and freedom. The civil economy is a reminder that while a good society is certainly the result of the market and freedom, there are needs associated with the principle of fraternity that cannot be overlooked nor relegated to the private sphere alone, in particular to philanthropy. At the same time, the civil economy is not on the side of those who challenge the existence of markets, who perceive the economic sphere as naturally conflicting with the good life, and who consequently call for a reduction in growth and the withdrawal of the "economic" from communal living. Rather, the civil economy proposes a multifaceted humanism where the market is not opposed or "controlled," but is seen as a civil arena on a par with others, that is, as one aspect of the public sphere; as something that if conceived and experienced as an open environment, also on the basis of the principles of reciprocity and gratuity, can contribute toward the construction of a civitas.

The core concern of the civil economy's plan could be summed up in the expression: the economy as if people mattered. To grasp the meaning of this conception of civil economy, just think of the two opposing ways of viewing the relationship between the economic sphere (which for convenience we may call the market in the broadest sense of the term) and the social sphere (which we may identify with the sphere of solidarity). 
On the one hand, there are those who see the extension of the market and the principle of efficiency as the solution to all of society's ills; on the other hand, there are those who see the market's advance as a form of "desertification" of society and thus try to protect themselves by establishing restrictions and creating counterweights to the market's force. The former consider the market as basically an "a-social" entity: from this viewpoint, which marks a return to certain forms of liberal ideology, the "social" is distinguished by market mechanisms that are seen as ethically and socially neutral. The market is required to be efficient and is tasked with creating as much wealth as is possible. Solidarity, on the other hand, starts where the market ends, since it concerns establishing the criteria by which the wealth produced is to be shared out, that is, with the redistribution of wealth.

The complete contrast to this vision is the other approach, which basically sees the market as an antisocial entity. This view harks back to Karl Marx and K. Polyani and is currently adopted in various forms of alternative economy on show (the solidarity economy, the social economy, the communitarian economy and so on). It is characterized by a conception of the market as a place of exploitation, where the strong bully the weak and thus as a threat to society as such. In Polyani's words, "The market advances over the desertification of society." Hence, the appeal to "protect society" from the market, based on the argument that truly human qualities (i.e., friendship, trust, giving, noninstrumental reciprocity, and love) would be destroyed by the advance of a market culture. This latter vision tends to see the economic sphere and the market as dehumanizing mechanisms capable of destroying the social capital that is indispensable for all truly human coexistence and sustainable economic growth.

The conception of the market-society relationship that characterizes the civil economy differs radically from the aforementioned two visions. The central idea of the civil economy is to experience human sociality within the framework of normal economic life, in other words, neither before, nor after, nor on the fringes of that life. It indicates us that principles other than profit and the exchange of equivalents can be accommodated within the framework of economic activity. This undoubtedly supersedes the first conception of the market as an ethically neutral space based exclusively on the principle of the exchange of equivalents, since it is the economic sphere itself which, depending on the presence or otherwise of these other principles, becomes either civil or uncivil. Moreover, it also supersedes the second conception of the market, which sees gifts and reciprocity as restricted to other moments or spheres of social life, and which to this day is still rooted in a variety of embodiments of the third-sector organizations. Such a vision is no longer tenable for at least two specific reasons (Bruni and Zamagni 2009).

First, in the age of globalization, the "two phases" logic (first enterprises produce wealth, and then the state intervenes to redistribute that wealth fairly) constituting the basis of the relationship between the economy and society (think of the Welfare State) no longer works, since the underlying foundation of that logic - the relationship between wealth and territory - no longer exists. Consequently, enterprises are required to pay particular attention to the social sphere during the course of their everyday activities. This is what is meant by the movement of ideas underlying "corporate social responsibility" (Zamagni 2013). The "Charter on Shared Social Responsibilities" approved by the Council of Europe on 22 January 2014 is clear proof of this. Second, there is the "displacement" effect. If the market, and the economy in general, equates simply with instrumental exchange, then this results in one of the greatest paradoxes of our time. "Bad money drives out good" states Gresham's Law, one of the oldest and most famous laws of economics. This mechanism has enormous consequences and operates every time that intrinsic motivation (such as reciprocity and gratuitousness) encounters extrinsic motivations (such as the profit motive): the bad ones drive out the good ones. Exchange based purely on the pursuit of personal interests, destroys other forms of human relationship; as a consequence, the market - left to its own devices - develops and "erodes" the basic premise of its very existence, namely trust and the propensity to cooperate with others.

In fact, all societies need to appeal to three different, complementary principles to develop in a harmonious manner and thus be capable of ensuring a future: the exchange of equivalents, the redistribution of wealth, and reciprocity. All societies are familiar with this "triad" of principles, even though only two of these principles have been incorporated each time into the models of social order that have succeeded one another over the course of recent centuries with unsatisfactory results in every case. Indeed, what happens if one of the three principles is absent? If we eliminate reciprocity, we get a model of social order based on the state-market dichotomy mentioned earlier. If we eliminate the redistribution principle, the result is compassionate capitalism (for example, American-style welfare capitalism). The market acts as a lever of progress and as such has to be left to operate unhindered, according to the advocates of neoliberalism. In this way, the market generates wealth, and the "wealthy" offer their "charity" to the poor, "utilizing" civil society organizations (the charities and foundations). On the other hand, the elimination or the 
underestimation of the exchange of equivalents leads to present and past forms of collectivism and communitarianism, where people live(d) in the belief that contracts are unnecessary (at the cost of devastating levels of wastage and inefficiency, however). Well, the central theme of civil economy is the pursuit of a social order where the three principles may coexist, that is, where they may find genuine room for their actual implementation, contaminating one another reciprocally.

To conclude and sum up then, the civil economy is a way of perceiving economic reality based on three fundamental theses. The first thesis is the rejection of the nonoverlapping magisteria (NOMA) principle first expressed by Richard Whately, the influential Oxford University economist, in 1829. According to the NOMA principle, ethical rules would have just as much an impact on economic science as they have on the laws of physics. In other words, the economic sphere should be kept separate from the ethical and political spheres with which it shares no common ground. Indeed, the infiltration into the market area of values and rules originating from the other two areas could endanger the pursuit of the market's ultimate objective, namely that of achieving efficiency. Therefore, if economic discourse wishes to gain scientific status (in the neopositivist sense), it must cut those ties - the umbilical cord in the words of Whately - that for centuries had united it to the worlds of ethics and politics. Of course, the civil economy cannot accept such a principle of separation - which is still the dominant view - for the simple reason that the object of the economic problem remains that of human being in its entirety. Thus, economics and ethics are intrinsically related, each reflected in the mirror image of the other. Economics must certainly be distinguished from, and rendered autonomous from, ethics and politics, but it cannot be separated from them.

The second thesis is that an important task of economic enquiry is to contribute toward the design of society's institutional arrangements, which cannot be considered an externally established given, as if it was, an objective reality. In other words, the civil economist cannot simply seek the optimal allocation of the resources available in compliance with a given set of rules of the game. This is so since not all (economic and political) institutions are equally capable of facilitating the obtainment of the common good, and thus a choice must be made of those that best ensure society's civil progress. This progress depends both on individual behavior and on the types of institutions that are selected.

Finally, the third thesis is that the three principles of market order - the exchange of equivalents, the redistribution, and reciprocity - must be interrelated in a multiplicative, rather than additive, manner. This means that all three principles must operate simultaneously if virtuous circles are to be created. There can be no trade-off between them, for example, reciprocity cannot be renounced to create more room for the exchange of equivalents, or vice versa. In other words, a basic tenet of civil economy is that of selecting as its ultimate purpose the common good - which is the multiplication of individual goods - and not the total good - which on the other hand is the sum of individual goods, as Bentham's utilitarianism imposes.

\section{The civil scaffolding of Sturzo's economic philosophy}

As previously mentioned, I argue here that Don Sturzo's thought basically belongs to the civil economy school. Even though his writings contain no mention of this expression, the fact is that his cultural background - like that of another great forgotten thinker, Antonio Rosmini and above all his insight into the real world are those of the civil economy. There is one significant thing, however, that could undermine this argument. Matteo Liberatore, from the Jesuit publication Civiltà Cattolica and one of the principal drafters of Rerum Novarum (1891), in 1889 published the Principi di economia politica: trattato (principles of political economy: a treatise), a treatise of neoclassical economic theory that reflected the thoughts of the Palermo-born Francesco Ferrara, Maffeo Pantaleoni, and Nicola Colajanni. Sturzo was invited to give a series of economics lectures to the Caltagirone seminary in 1900, and on that occasion he adopted Liberatore's work as his course book. It should be pointed out that the Jesuit, who hailed from the town of Salerno just like Antonio Genovesi, did not even mention the latter's work Lezioni di Economia Civile (lessons in civil economy), published in Naples in 1765 and the inspiration for several sections of Adam Smith's "The Wealth of Nations." The current paper is not the appropriate place for a full rational reconstruction of Sturzo's cognitive map, which would point out to the unsubstantiated character of the interpretation according to which Sturzo lent heavily toward the economic mainstream of his time. I shall merely offer a few brief observations which in my opinion suffice to negate this reductionist reading of Sturzo's work.

"The modern error - one reads in Politica e morale consists in separating and counterposing Humanism and Christianity: Humanism has been turned into a divine entity, while the Christian religion has been seen as a private affair, a matter of individual conscience, or even 
a sect... We need to re-establish the union between the Human and the Christian." ${ }^{4}$ Sturzo opposed the view of the world underlying the economic mainstream of his time, due to his sincere, convinced acceptance of the Catholic social doctrine. In particular, he could not accept the idea of historical development having a purpose that only science can fully achieve, or the idea of a purely instrumental rationality deriving from axiological individualism. Neither could he accept the belief that the spirit of capitalism had to be protected through the potestas (power) of the state. However, all of this did not prevent him from looking for a compromise, in historical terms and not at the level of principles, between Catholic ethics and the spirit of capitalism and between the energy that capitalism can release, and the ethical-institutional framework that Catholicism offers. The point is that Sturzo was well aware of the fact that while the market economy is the genus, capitalism is only one species of that genus and as such may evolve and mutate morphogenetically: this can happen in relation to the prevailing system of values in a given culture and in a specific historical context.

One should not forget that the context in which Luigi Sturzo's thoughts took shape was that of modernism characterized by antireligious secularization and positivist rationalization. It was because of his awareness of the unacceptable limitations of this conception that Sturzo understood that to guarantee the sustainability of a vital market economy values need to be continually imported into that economy from outside the market itself. Sturzo entered politics following an intense period of social action subsequent to publication of the encyclical letter Rerum Novarum by Pope Leo XIII and as a result of Sturzo's close acquaintance with figures from the Catholic Church's social movement, such as Giuseppe Toniolo and Romolo Murri. Thus I would argue that, with hindsight, Sturzo anticipated what is today known as the paradox of Böckenförde (2007), according to which the secular liberal state exists on the basis of premises that it itself cannot guarantee. The paradox consists of the idea that the liberal state can only exist if the freedom, that it promises and guarantees for its citizens, is part of the moral constitution of individuals and of those social structures pursuing the common good. If, on the contrary, the liberal state itself attempts to guarantee such regulation, by availing itself of coercive powers, then it stops being liberal and ends up falling foul of that totality that it purports to free itself from.

4 Sturzo 1972, p.130. Note that the humanism that Sturzo referred to in his passage is not the civil humanism of the early 15 th century, but the "uncivil" humanism of the late 15th century (Bruni and Zamagni 2009).
Sturzo showed that he fully understood the significance of this paradox when he pointed out that the market requires the equality of all participants, but at the same time it generates unequal results thereafter. Therefore, when the equality-of-being diverges too much, and for too long, from the equalityof-having, it is the market mechanism itself that is faltering and producing perverse results. In this regard, Economia e morale, published in March 1947, reads as follows:

\footnotetext{
"It is rightly claimed that the specific aim of the economy is profit, but in order to evaluate the significance of such profit, its meaning and character need to be specified. The profit that is the purpose of the economy is of a social character... The purpose of the economy is never individual, but always social, because the individual alone, operating alone, does not, and cannot, exist; the individual is social.... This is the point at which morality affects the economy, when individuals ask themselves what the grounds for, and the limits on, the use of goods are. Theft is by nature utilitarian, of course; the thief wants to be able to achieve enjoyment of a good by the quickest route possible; if the economy were individualistic, he would have solved the problems of the squaring of the circle ... His [the thief's] economy is bankrupt because the moral basis on which it rests is bankrupt." 5
}

You do not need to be an expert analyst to understand the true depth of Sturzo's anti-(Benthamian) utilitarian stance and to realize just how far removed Sturzo's thought is from the fundamental propositions of welfare economics of wealth, the true pillars of liberal economic thought. Indeed, in the introduction to his Premesse della Politica published in 1945, Giorgio La Pira wrote that to design a new political architecture of Christian inspiration, both Maritain and Don Sturzo would need to be involved (Pagliai 2009, p.30). If you have the patience to read Per una architettura cristiana dello Stato by La Pira (1954) with an open mind, you will discover not only the degree to which the Mayor of Florence was intellectually indebted to Sturzo but also, more importantly, that the two agreed on the distinction between the principle of statehood (to be welcomed) and that of statism (to be condemned).

A passage revealing Sturzo's conception of civil economy can be found in the paper entitled Sociale, parola magica (the magic word "social") published in the Italian newspaper II Giornale d'Italia on 26 August 1958. In arguing against Keynes and Beveridge, whose ideas,

5 Quoted in Palladino 2009, pp.158-160 (author's translation). 
in Sturzo's view, could work only in the English-speaking world, he wrote:

\begin{abstract}
"Today they [his Italian political rivals] go to any length to give the impression that they've discovered the Welfare State, because they've read Lord Beveridge's book, articles in the Esprit, a few pamphlets by Maritain, and God knows that they haven't become imbued with the ideas of a socialism that eats away at the bones of certain young Catholics who discover new ideas they were unaware of under Fascism, or that they believed could be found in the corporatism of the one-party State. The Welfare State existed before it was discovered, because the pursuit of the common good is a function of the State." 6
\end{abstract}

Sturzo's opposition to both laissez-faire politics and statism was one that he shared with La Pira, who also raged against the mysticism of the state which he declared to be "the most serious heresy of our time." Of course, if one remains within the confines of the liberalist-statist dichotomy - as the paradigm of the political economy implies - then Sturzo can clearly be classified in the liberalist camp, while La Pira would be closer to the statist camp. This is not the case, however, if one adopts the triadic scheme characteristic of the civil economy, which sees the market, the state and intermediary social bodies acting together, on the basis of subsidiarity, in view of the universal common good. Thus, the differences between these two thinkers, which certainly remain, were differences of degree rather than of principle.

In other words, if reciprocity (and thus the principle of gift, which is the prime mover of reciprocity) is removed from the market's operation, and consequently the economic question becomes one giant prisoner's dilemma, then it is clear that in the adverse phases of the economic cycle there is no other way of interrupting the virtuous circle than by having recourse to the power of the state. The state steps in to fill the void left by the general lack of trust, through its implementation of specific public spending programs. Roosevelt's actions were a good example of this: despite not being a convinced Keynesian in any way, in his first presidential speech in March 1933 Roosevelt, in an attempt to restart the economy that had been halted by the 1929 economic crisis, had to promise that the State would personally ensure that it "...put people to work. ...[this task] can be accomplished in part by direct recruiting by the Government itself." However, it is the practice of reciprocity that

6 Quoted in Pagliai 2009, p.63 (my italics).

7 Roosevelt 1957, p.92. For example, through the creation of the Civil Works Administration, of the Federal Emergency Relief Administration, of the Works Progress Administration, and so on. creates, through a bottom-up, endogenous process, those relationships of mutual trust without which the market cannot function; the state certainly does not do this. This is why statism is an "evil beast" in the famous words of Luigi Sturzo.

Basically, Sturzo's philosophy is underpinned by his conception of civil society as a vital world found on two essential principles: the social principle and a universalist orientation. If only the first of these two principles were to operate, then civil society would extend no further than the confines of the private sphere. In fact, the social principle is essentially the principle of self-organization which, as such, does not possess the force required to put universalistic principles into practice. Sociality, that is, the propensity to live together, is not a defining characteristic of human beings, as it is also one shared by animals. Therefore, what lends civil society its public value - but not its political value of course - is the second factor, the universalist orientation.

According to this conception, civil society, as one of the two constituent parts of the public sphere, contributes not only to enrich social dynamics but also, above all, to avert two dangerous risks which would have opposing consequences but which are based on similar foundations. On the one hand, there is the risk of social privatism (the individual's well-being is perceived to be in opposition to, or at the very least independent of, the well-being of others); on the other hand, there is the risk of totalist statism (whereby state policy tries to defend itself against intermediate entities, in the name of the national or collective interest).

\section{Sturzo and the SOME}

Could it be argued that Sturzo was a supporter of, if not exactly a believer in, the SOME, that is, that specific form of liberalism known as the liberalism of the rule, as opposed to the liberalism of the $a t^{8}$ championed by the Manchester school of laissez-faire liberalism? I personally do not believe that such an argument can be made. In this regard, I would like to summarize the essential characteristics of the SOME, an expression originally coined by Alfred Müller-Armack (on this subject, see Felice 2013). In the opinion of Walter Eucken (18911950), one of the thinkers who forged the conceptual framework of the SOME, the economic system needs to be guided starting from certain "formative principles" establishing the nature and essence of the market

8 The author obtains the distinction between the liberalism of the rules and the liberalism of the act, by analogy, from that between the utilitarianism of the rules and the utilitarianism of the act first introduced by the Oxford economist Roy Harrod in 1936. 
economy and from "regulatory principles" establishing the manner in which the economy is to operate. The former include the primacy of monetary policy, designed to guarantee the stability of the currency as well as the opening of markets to free competition, the safeguarding of ownership rights, press freedom, and the continuity of operation of the state's economic policy. The regulatory principles, on the other hand, concern the fight against the formation of natural monopolies together with income policy designed to guarantee the fair distribution of resources, state intervention aimed at correcting various negative externalities through a system of taxes and subsidies, and governmental intervention in the labor field, which cannot be left to the dictates of market laws. A similar approach was taken by Wilhelm Röpke - one of the most influential thinkers behind the SOME, whose work civitas humana (1947) called for a "strong state" capable of guaranteeing the security and "intelligent policing of the markets" (sic!), given that the markets are themselves incapable of self-government or self-adjustment (regarding Röpke, see the important work by Franco 2016).

Basically, the SOME is an economic model based on the state-market dyad that tasks the market with producing wealth, and the state with establishing the rules of the economic game, ensuring that those rules are complied with and distributing wealth to the poorer classes in accordance with the principle of equity. In fact, civil society is at the service of the state in this model. The SOME has been the only Western model capable of competing with the laissez-faire model. It has permitted the achievement of solidarity and social cohesion that has made Germany great. The pillars of this model are a strong state capable of earning the respect of others (e.g., when it demands compliance with anti-monopoly regulations), and the idea that solidarity should go hand to hand with efficiency. "The state's role in the social market economy" - written by Antiseri in the paper "But the social market economy is not dead" - is not simply that of night watchman, as it is in economic liberalism, but that of a strong State capable of preventing the assault on the market's operation by monopolies and rent-seekers" (Antiseri 2017, p.59).

Well, with his profound knowledge of Italy and of events during the tragic experience of fascism, Sturzo had many reasons to believe that the model would have been taken, in practice, to signify a reformulation of the corporatist social order, given the ample, invasive role that the model afforded to the state (indeed, it should be remembered that SOME model was adopted by the German CDU [DCs] in 1949, and subsequently by social democrats [SPD] in 1959). On the one hand, the General Confederation of Italian Industry (Confindustria) did not want to know about comanagement and conduct monitoring or the exchange of information among economic players, which are all fundamental aspects of the SOME model. Even Pasquale Saraceno was not at all keen on the idea of worker participation. It should be noted that the "management committees" (Consigli di Gestione) provided by a Decree issued in April 1945 by the Ntaional Liberation Commettee for Norther Italy which was not ratified by the allied military government and referred to in Article 46 of the Italian Constitution, were never instituted by law following the abandonment of the Morandi project by the then prime minister Alcide De Gasperi. On the other hand, the three main political parties at the time openly manifested their distrust of private enterprise: the Italian Communist Party $(\mathrm{PCI})$ and the Italian Socialist Party (PSI), for obvious ideological reasons, and the left wing of the DCs due to their perception of capitalism as a social order that was contrary to the Church's social doctrine. At the same time, Sturzo clearly could not commit himself to the model of SOME adopted in the English-speaking world (and rightly so). It is generally acknowledged that the distinction between the two models lies in the different ways that entrepreneurs liaise and cooperate to control wages, encourage innovation, and favor adjustment to changing market conditions. On the basis of the civil economy paradigm, what Sturzo had in mind was a civil market economy founded on the state-market-organized civil society triad. The latter element, however, was conceived as pursuing productive functions rather than mere redistributive functions.

Moreover, while the philosophical basis of the SOME consists of the deontological ethics of Kant, Sturzo's philosophical mold is a personalism deriving from Thomism. There is not sufficient room here to elucidate the difference between these two positions: suffice it to say that from the deontological viewpoint, what is just prevails over what is good, to the point that fiat iustitia, pereat mundus (literally: let justice be done, though the world may perish; I. Kant); from the personalist perspective, on the other hand, the good should prevail over the just, as Aristotle had already affirmed. Therefore, it should come as no surprise that in the aforementioned paper, Sociale, parola magica, Sturzo declared that:

"The use of the term 'social economy' rather than 'political economy', favoured by certain economists, is not a recent thing: such economists believe the political economy to be based on market freedoms, while the social economy is based on state intervention... The improvement that is referred to when using the misused, equivocal word 'social' is not achieved through the 
dissipation of State funding in unproductive activities, but through an increase in general well-being, in productivity, in the personal, private initiative and vitality of each citizen... If the socialists fail to comprehend this, the reason for this is their 'anti-social' theories; but the fact that certain Catholics also fail to understand it, priests included, appears absurd to those who know that the basis of Christianity is the defeat of egoism and the triumph of justice and human fraternity." 9

Finally, there is a third circumstance that would point to Sturzo's nonalignment with the SOME approach. This factor is the considerable room that Sturzo affords - in full accordance with the civil economy message - to civil society's organizations on the economic level as such, rather than simply on the cultural and political levels. This is demonstrated, first and foremost, by the man's own biography: Sturzo was a leader of social Catholicism who worked for, and concerned himself with, the creation of rural banks, the setting up of manufacturing and workers' cooperatives, the establishment of community foundations, and the fierce defense of municipalism and regionalism as a means of achieving the independence of local areas and communities, without involving the disintegration of the nation. In this, his experience as deputy mayor of Caltagirone proved to be of significant importance.

Therefore, why exactly did Luigi Sturzo give such importance to entities operating indeed within the market and following a business logic, but without any profit motive, that is, to what we now refer to as "nonprofit" organizations? The answer is that Sturzo was fully aware that the capitalistic market does not "exude" competition, but tends naturally toward monopoly. Adam Smith had foreseen this phenomenon in his Wealth of Nations (1776), when he observed that two hands, rather than one, were needed to get the market to work: one invisible hand operating by means of that mechanism known as the heterogenesis of ends and one visible hand operating through public powers. The great insight offered by Sturzo's economic thought was that the most effective form of defense against the risks of economic monopoly was not state intervention, but the pluralism of enterprise, that is, economic biodiversity. According to Sturzo, the market should comprise capitalistic undertakings, social undertakings, cooperatives, and public benefit companies, all operating on a level playing field without the legislative-institutional framework favoring one form or another. It is the competition between different forms of enterprise, and not just between enterprises of the same kind, that guarantees both the proper functioning

9 Cited in Palladino 2009, pp.130-132 (author's translation). of the market and true freedom of choice for consumers. All of this is not present in the SOME. Basically, the necessary requirements of a SOME are too similar to those called for, to establish fairness, by John Rawl's "Theory of justice" published in 1971 (the first formulations of which, however, go back 15 years earlier), for them to be accepted with all his heart by a figure like Sturzo.

The foregoing argument may be generalized considering the two prevailing views taken by political philosophers regarding the way of seeing the relationship between political society and civil society. Originally, these two expressions were considered synonymous. Aristotle's Koinonia politiké corresponded, in fact, to the civilis societas of which Cicero spoke in De Repubblica. It was only from the 17th century that the meanings of the two concepts were distinguished; this distinction remains to the present day. This separation of political society from civil and society has led to the emergence of two different approaches. In the words of the famous English political scientist "M. Oakeshott," the choice is between politics as "enterprise association" and politics as "civil association." The first conception, which goes back to Thomas Hobbes and to some degree presupposes an organismic vision of society, sees politics as that activity designed to guide society in a given direction. Thus, the political sphere coincides perfectly with the political sphere and the latter with the Leviathan State. In this vision of politics, political parties are comparable to the management of a large company that has to try and render the demands of various stakeholders compatible with one another. Civil society, on the other hand, is the sphere of particularistic interests which can indeed be expressed freely, provided they do not hinder the work, or question the steering role, of the government, the ultimate expression of the universal. The second conception, on the other hand, harks back to the liberal-democratic political ideal championed by John Locke. This vision does not accept that the public sphere is completely taken up by political parties, which are certainly essential actors, but not the only ones, on a stage where there is also room for social actors. In other words, this vision does not accept that social actors are subsumed under political parties, for the simple reason that from the personalist perspective, people are capable of socializing even before they subscribe to the social contract.

What are the consequences of these two visions of politics for the purposes of the current discourse? First, they entail different interpretations of the principle of subsidiarity. While politics as "enterprise association" favors negative subsidiarity, consisting in preventing freedoms being removed (never deprive lesser social units of their autonomy), politics as "civil association" on the other hand places the emphasis on positive 
subsidiarity, consisting in a duty to help, putting the social sphere at the service of individuals. In the first case, subsidiarity is, in practice, a governmental technique, while in the second case it is a principle of social order. Another important consequence is the feasibility or otherwise of adopting the most important practices of deliberative democracy. These practices are all rooted in the idea of reaching the most important decisions such as those regarding local government, large-scale infrastructures, and environmental protection - by involving all parties concerned, or their representatives, on the basis of the provision of due information and opportunities for dialog (it should be noted here that deliberative democracy is the opposite of participatory democracy: the former requires a series of wellorganized intermediate bodies; the latter only requires well-informed individuals). Clearly, only politics as "civil association" can give rise to all those institutions representing a necessary precondition for popular participation of the deliberative kind. The alternative conception of politics as "enterprise association" may at the very most ensure involvement through consultation and the submission of petitions (e.g., as happens in a referendum); however, it is clear that it cannot avert the risk of demophobia (the irrational fear of crowds). As we know, there are many ways of interpreting the concept of ochlophobia. The most famous of these is the traditional oligarchical way, which is no longer fashionable. A more refined mode in the current-day societies is that of J. Schumpeter's elitist-competitive model, according to which political decisions should be taken by the appointed elites, since they alone can guarantee efficiency. Thus, what are required are, on the one hand, electoral laws of a majoritarian nature sanctioning the distinction between useful votes and useless votes, and on the other hand, intermediate bodies that cannot undermine governability.

It is interesting to return to the prophetic words of Jacques Maritain, who set out in his famous work "Man and the State," to explain the difference between political society and civil society: "The people is the multitude of human persons united by a mutual friendship for the common good.... who constitute a political society or the body politic. The people is not for the State. The State is for the people." (Maritain 2003, p.29). In Maritain's view, the aforementioned distinction is necessary to "avert the risk of degeneration in agreeing on everything...the religious authorities for the entire Church, the State for the entire body politic. At the same time, the State tends to assign itself a specific common good, that is, its own preservation and growth, separate ... from the common good that is its ultimate purpose" (Maritain 2003, p.17).

\section{By way of conclusion}

"Roses have thorns and silver fountains mud" (W. Shakespeare, Sonnet XXXV). I believe that Shakespeare's words aptly sum up the life and times of Luigi Sturzo. All great ideas are subject to the phenomenon of the heterogenesis of ends, and great men often fall victim to incomprehension and misrepresentation. We know that memory is essential if ideas are to hit the heights, since memory is the permanence of the past, capable of guiding us forward. It is not true to say that thought moves more freely in a vacuum. Without memory, thought tends to uncritically repeat the same mistakes; as in the case of those who, although acting in good faith, are prepared to put at risk the common good of the civitas to see their own point of view prevail. In this regard, the following aphorism of David Hume comes to mind: "It is not against reason that I should prefer the destruction of half the world to the pricking of my little finger." This is the outcome of many individualisms and group egoisms that have sadly characterized the political experience of Italy's Catholics from the postwar years to the current day.

As we all know, great works are not achieved "in" time but "for" time. History has shown that Etienne Gilson, a friend and admirer of Maritain, was right when he wrote the following to Maritain on 29 January 1953: "Dear friend, I think we worry too much about our failures ... Whether you know it or not, you are one of the greats, and you will never be forgiven for that. You'll pay above all for this fact" (Gilson and Maritain 1991, p.189). I think that the same thing could be said of Luigi Sturzo, albeit mutatis mutandis. The main message that this Catholic thinker from Caltagirone has for today's politicians is that alliances, rather than contract, social, or otherwise, lie at the center of political action. The term "alliance" should be conceived of as indicating a frontier defining the common identity of those who come together in the alliance. A frontier is different from a boundary: while the latter closes, the former opens. A boundary is a demarcation line separating those within from those outside. A frontier, on the other hand, is a transit and stopover area along a route where change is experienced. This is why an alliance postulates diversity, which is not the same thing as difference. In fact, those who come together to form an alliance do so not to build walls, but to construct bridges between all those who pursue the same ends, even if their points of departure differ. Sturzo was fully aware that while the political theories and practices based on the notion of the social contract are certainly capable of accounting for social life, at the same time, they cannot explain why it is good that people live in a society and why it is good to apply the provisions of law 
to ensure that the grounds of the civilitas are preserved in time. Sturzo was a true master in this sense.

The civil economy line of thought - a typical Italian line of thought - that Sturzo proved capable of interpreting and revitalizing, sees cultural differences as an opportunity for harmony rather than conflict. Industrial society has pursued and achieved the homologation and standardization first of products and then of cultural models. Postindustrial society, on the other hand, exalts and favors differences. However, if those differences are not duly channeled, they are transformed into systemic inefficiencies. Laws and contracts are no longer sufficient, even when well designed, to guarantee a social order capable of meeting the news challenges. What is required is the utilization of the resources of homo reciprocans, because homo economicus, with the best will in the world, is incapable of resolving any of the major social problems of our age. Antonio Genovesi had understood as much well before his time, when in his work Lezioni di Economia Civile (Lessons on Civil Economy -1765), he wrote homo homini natura amicus in clear contrast to Hobbes' homo homini lupus.

\section{References}

Antiseri D., Ma l'economia sociale di mercato non è morta, Vita e Pensiero, 5, 2017.

Böckenförde E.W., Diritto naturale e secolarizzazione, Rome, 2007.

Bruni L., Sugden R., Fraternity: why the market need not be a morally free zone, Econ Philos, 24 (1), 35-64, 2008.

Bruni L., Zamagni S., The Civil Economy, Newcastle u.T., Agenda, 2016

Bruni L., Zamagni S. (Eds.), Dizionario di Economia Civile, Città Nuova, Rome, 2009.

Campanini G., II pensiero politico di Luigi Sturzo, Sciascia, Rome, 2001.

de Cusa Nicolai, Opera omnia, (ed.by Ernst Hoffmann et al.), Amburgo, Felix Meiner, 1932-2006, vol. 1, p.267.

De Rosa G., Luigi Sturzo, Utet, Turin, 1977.

Felice F., Istituzioni, Persona, e Mercato, Soveria Mannelli, Rubettino, 2013.

Franco G., Economia senza etica? II contributo di Wilhelm Röpke all'etica economica e al pensiero sociale Cristiano, Soveria Mannelli, Rubettino, 2016.

Genovesi A., In: Perna M.L. (Ed.), Lezioni di commercio o sia di economia civile, Napoli, 1765-1767, 2005.

Gilson E., Maritain J., Correspondance 1923-1971, In:
I would like to end here by citing a passage from John Ruskin that has become a classic of the social sciences: "At a severe crisis, when lives in multitudes, and wealth in masses, are at stake, the political economists are helpless-practically mute; no demonstrable solution of the difficulty can be given by them, such as may convince or calm the opposing parties" (Unto This Last, 1862). Perhaps, this was the passage that Vilfredo Pareto was thinking of when in a letter to Maffeo Pantaleoni dated 30 April 1896, he wrote: "Each day I'm increasingly convinced that there is no more meaningless study than that of political economics. Tell me: if that science had never been studied, would we be in a worse position than we currently are in?.. All our political economy is nothing more than empty talk". Of course, if the great economist Pareto, and above all Pantaleoni, had understood the key message of the civil economy and had refrained from ostracizing it with all their energy (and all their academic power), then they would certainly not have reached such a cynical conclusion, and the study of economics would probably have taken a very different course, one that better serves the cause of integral human development.

Prouvost G. (Ed.), 1991, Librairie Philosophieque, Vrin, Paris, 1991.

La Pira G., Per una architettura cristiana dello Stato, Libreria Editrice Fiorentina, Florence, 1954.

Liberatore M., Principi di economia politica: trattato, Befani, Rome, 1889.

Maritain J., L'uomo e lo Stato, Marietti, Genoa, 2003.

Mises L.V., Liberalismus, Verlag von Gustav Fischer, Jena, 1927.

Pabst A., Political economy of virtue: Genovesi's civil economy alternative to modern economic thought, International Rev Econ, 14, 2015.

Pagliai L., Per il bene comune: poteri pubblici e economia nel pensiero di G. La Pira, Ed. Polistampa, Florence, 2009.

Palladino G. (Ed.), Il pensiero economico di Luigi Sturzo, II Sole 24 Ore, Milan, 2009.

Pennisi M., Fede e impegno politico in Luigi Sturzo, La Società, 2, 197, 2009.

Roosevelt F.D., In: Rauch B. (Ed.), The Roosevelt Reader, Winston, New York, 92, 1957.

Sturzo L., Politica e morale. Coscienza e politica, Zanichelli, Bologna, 1972.

Zamagni S., Impresa responsabile e mercato civile, II Mulino, Bologna, 2013. 
